\title{
Factors Associated with the Utilization of Institutional Delivery Service among Mothers
}

\author{
Pratima Pathak, ${ }^{1}$ Shovana Shrestha, ${ }^{1}$ Rashmi Devkota, ${ }^{1}$ Basanta Thapa ${ }^{2}$ \\ ${ }^{1}$ Nepal Medical College, Jorpati, Kathmandu, Nepal, ${ }^{2}$ Chitwan Medical College, Bharatpur, Chitwan, Nepal.
}

\begin{abstract}
Background: Assessment of utilization of institutional delivery services is crucial to reduce risk of maternal mortality and morbidity in countries like Nepal. This study was conducted to find out the proportion of utilization of institutional delivery service and associated factors among mothers.

Methods: Data was collected from the total of 129 mothers of Kathar VDC, Chitwan district who delivered baby within last one year proceeding the period of data collection using census method. Descriptive statistics and binary logistic regression analysis were applied.

Results: Out of 129 mothers, $78.3 \%$ had their delivery in the health facilities. Binary logistic analysis showed number of factors associated with utilization of institutional delivery service such as ethnicity, respondents educational level, number of pregnancy, number of ANC visit and birth preparedness status. But in the multivariable logistic regression analysis, no. of ANC visit $(\mathrm{AOR}=10.03,95 \% \mathrm{CI}=1.02-98.29)$ was only independent factors affecting institutional delivery service utilization.

Conclusions: A number of factors have been shown to affect the utilization of institutional delivery. Therefore, concerned authority should plan and implement awareness programme aiming at increasing antenatal clinic visits and utilization of institutional delivery service.

Keywords: Factors; institutional delivery; maternal health; nepal; utilization.
\end{abstract}

\section{INTRODUCTION}

Maternal mortality is unacceptably high as evidenced by $62 \%$ of the total global maternal deaths carries by SubSaharan African region followed by $24 \%$ by South Asian region. ${ }^{1}$ Even though, MMR in Nepal has dropped from 539 to 281 per 100,000 live births (between 1996 and 2006) and to 190 per 100,000 live births in 2013, yet it still has the highest mortality rate among south Asian countries except Afghanistan. ${ }^{1}$

In Nepal, high proportion of maternal deaths is most likely due to the fact that over $63 \%$ of births take place at home. ${ }^{2}$ Evidence suggests that appropriate delivery care and skilled attendance at birth ensures safe delivery and helps to identify the onset of complications in time. ${ }^{3}$ Therefore, an in-depth understanding of the factors associated with the utilization of institutional for delivery services is of paramount importance to unleash the barriers for promoting utilization of institutional delivery among women of Nepal.

\section{METHODS}

A community based descriptive cross-sectional research design was used for this study to meet its objectives. This study was conducted in Kathar village development committee (VDC) of Chitwan district of Nepal which is considered to be the second most developed district after Kathmandu- the capital city (148 kilometers far from the capital city).A total of 129 mothers who gave birth in last one year preceding the period of data collection were included in the study using census method. Data collection took place between 2071-0622 to 2071-07-5 and 2071-07-13 to 2071-07-27. The list of the mothers were taken through Female Community Health Volunteers (FCHVs) records as FCHVs keep a record of all pregnant women and mothers who have given birth. Study was conducted after receiving the ethical clearance from Chitwan Medical CollegeInstitutional Review Committee and formal permission to collect data from the authorized body of Kathar V.D.C. Further, verbal consent was obtained from

Correspondence: Pratima Pathak, Nepal Medical College, Jorpati, Kathmandu, DOI: http://dx.doi.org/10.3126/jnhrc. $\mathrm{v} 15 \mathrm{i} 3.18845$

Nepal, Email : pathakpratima6@gmail.com, Phone: +977 9845073687. 
each respondent. Respondents were clearly explained that they have choice to reject or discontinue from the research study at any point of the study time. Confidentiality was maintained throughout the study and thereafter. Content validity of the instrument was established by consultation with research advisor and subject experts. English questionnaire was translated into the local Nepali language to maintain simplicity and comprehensibility with the help of language expert. Besides, pre testing was done among $10 \%$ of mother (i.e. 13 mothers) to assess the practicability of use of the instrument and was excluded in the main study. Slight modifications were done in the instrument such as in ordering of questions and adding/deleting some response categories after pretest.

A face to face interview technique was applied to collect data using a semi-structured questionnaire which lasted for around 20-25 minutes for each respondent. The collected data was coded, checked, reviewed, and organized daily for completeness. Coded data was entered in Epi data 3.1 and entered data was exported to IBM SPSS version 20. Descriptive statistics (frequency, percentage, mean and standard deviation) and inferential statistics (chi square test, binary and multivariable logistic regression) were used for statistical analysis. Statistical significance was considered at $p<0.05$ and the strength of statistical association was assessed by odds ratios with $95 \%$ confidence intervals.

\section{RESULTS}

Age of respondents ranged between 19 and 35 with the mean age being 25.37 ( $S D=3.26)$. Nearly half 59 (45.7\%) of the respondents were from the age group 25-29 years. Sixty nine $(53.5 \%)$ of the respondents were from janjatis ethnicity. Forty one $(34.2 \%)$ of the respondents and 49 (38.6\%) of the respondents' husbands had completed higher secondary and above level of education (Table 1 ).

Present study revealed that the mean age at first pregnancy of respondents was 21.26 (3.12) years. Cent percent of respondents were found to have ANC visit in various levels of health care facilities. Among them, 96 (74.4\%) of the respondents had visited ANC clinic four and more than four times. Birth preparedness were assessed through questions which included several components of birth preparedness such as: saving money, arrangement of transportation, arrangement of blood donor, identification of a place of delivery, arrangement of safe delivery kit, arrangement of foods and clothes.
Respondents who had made necessary preparation of two or more components of birth preparedness were categorized as prepared and this represented 90 (69.8\%) of respondents (Table 2 ).

Regarding the awareness of danger signs, respondents who could give two or more right answers of danger conditions were considered as well aware, who could answer one right response was considered some aware and those giving incorrect response or no response were considered as unaware. The finding revealed that only $29(22.5 \%)$ of the respondents were well aware of danger signs during childbirth (Table 2).

\begin{tabular}{|c|c|c|c|}
\hline Variables & Frequency & Percent & Mean \pm SD \\
\hline \multicolumn{4}{|c|}{$\begin{array}{l}\text { Age group in } \\
\text { years }(n=129)\end{array}$} \\
\hline $15-19$ & 2 & 1.6 & \\
\hline $20-24$ & 56 & 43.4 & $25.37 \pm$ \\
\hline $25-29$ & 59 & 45.7 & 3.26 \\
\hline$\geq 30$ & 12 & 9.3 & \\
\hline \multicolumn{4}{|c|}{ Ethnicity $(n=129)$} \\
\hline Dalit & 18 & 13.9 & \\
\hline Janajatis & 69 & 53.5 & \\
\hline Upper caste & 42 & 32.6 & \\
\hline \multicolumn{4}{|c|}{$\begin{array}{l}\text { Educational status of } \\
\text { respondents }(n=129)\end{array}$} \\
\hline Literate & 120 & 93.0 & \\
\hline Illiterate & 9 & 7.0 & \\
\hline \multicolumn{4}{|c|}{$\begin{array}{l}\text { Educational level of } \\
\text { respondents }(n=120)\end{array}$} \\
\hline $\begin{array}{l}\text { Read and } \\
\text { write only }\end{array}$ & 14 & 11.7 & \\
\hline $\begin{array}{l}\text { Primary } \\
\text { education }\end{array}$ & 31 & 25.8 & \\
\hline $\begin{array}{l}\text { Secondary } \\
\text { education }\end{array}$ & 34 & 28.3 & \\
\hline $\begin{array}{l}\text { Higher } \\
\text { secondary } \\
\text { and above }\end{array}$ & 41 & 34.2 & \\
\hline \multicolumn{4}{|c|}{$\begin{array}{l}\text { Educational status of respondent's } \\
\text { husband }(n=129)\end{array}$} \\
\hline Literate & 127 & 98.4 & \\
\hline Illiterate & 2 & 1.6 & \\
\hline
\end{tabular}




$\begin{array}{lcr}\begin{array}{l}\text { Educational level of respondent's } \\ \text { husband(n=127) }\end{array} & \\ \begin{array}{l}\text { Read and } \\ \text { write only }\end{array} & 8 & 6.3 \\ \begin{array}{l}\text { Primary } \\ \text { education }\end{array} & 42 & 33.1 \\ \begin{array}{l}\text { Secondary } \\ \text { education }\end{array} & 28 & 22.0 \\ \begin{array}{l}\text { Higher } \\ \text { secondary } \\ \text { and above }\end{array} & 49 & 38.6 \\ \end{array}$

Table 2. Obstetrics characteristics of Respondents $(n=129)$.

Variables Frequency Percent Mean \pm SD

$\begin{array}{lrrr}\text { Age at first pregnancy }(\mathrm{n}=129) & & \\ 15-19 & 50 & 38.8 & \\ 20-24 & 63 & 48.8 & \\ 25-29 & 14 & 10.9 & 21.26 \pm 3.12 \\ \geq 30 & 2 & 1.6 & \\ \text { Number of pregnancy }(\mathrm{n}=129) & & \\ 1 & 55 & 42.6 & \\ 2-4 & 72 & 55.8 & \\ \geq 5 & 2 & 1.6\end{array}$

Period of gestation at time of first ANC visit $(n=129)$

$\begin{array}{lll}1^{\text {st }} \text { trimester } & 76 & 58.9 \\ 2^{\text {nd }} \text { trimester } & 53 & 41.1\end{array}$

No. of ANC

visit $(n=129)$

$\begin{array}{lll}<4 & 33 & 25.6 \\ \geq 4 & 96 & 74.4\end{array}$

Birth preparedness status $(\mathrm{n}=129)$

$\begin{array}{lll}\text { Prepared } & 90 & 69.8 \\ \text { Not prepared } & 39 & 30.2\end{array}$

Place of delivery of previous baby $(n=73)$

\begin{tabular}{lrr} 
Home & 19 & 26.0 \\
Health facility & 54 & 74.0 \\
$\begin{array}{l}\text { Level of Awareness of danger } \\
\text { conditions }(\mathrm{n}=129)\end{array}$ & \\
Unaware & 49 & 38.0 \\
Some aware & 51 & 39.5 \\
Well aware & 29 & 22.5 \\
\hline
\end{tabular}

Out of total 101 respondents, 129 (78.3\%, $95 \% \mathrm{Cl}$ : $0.712-0.854$ ) of the respondents had delivered their last child in health care facility while $28(21.7 \%$ had home delivery). Of those who delivered in health care facility, $79(61.2 \%)$ had delivered in district hospital, 21 (16.3\%) delivered in private level hospital while the least 1 $(0.8 \%)$ in Primary level health facility (Table 3 ).

\section{Table 3: Institutional Delivery Service Utilization} Status $(n=129)$.

\begin{tabular}{|lr|}
\hline Variables & $\mathbf{n}(\%)$ \\
\hline Home & $28(21.7)$ \\
\hline Institutional: & $101(78.3 \%)$ \\
\hline District hospital & $79(61.2)$ \\
\hline $\begin{array}{l}\text { Primary Health Care Centre/Health } \\
\text { post/Sub-health post }\end{array}$ & $1(0.8)$ \\
\hline Private hospital/Clinic/Nursing home & $21(16.3)$ \\
\hline
\end{tabular}

Data depicts that respondents' socio-demographic factors such as ethnicity $(\mathrm{COR}=51.25 ; 95 \% \mathrm{Cl}=5.73-458.28$; $\mathrm{p}<0.001)$, educational level of respondent $(C O R=17.75$; $95 \% \mathrm{Cl}=4.15-75.91 ; \mathrm{p}<0.001)$, respondents' husband education $(\mathrm{COR}=43.20,95 \% \mathrm{Cl}=6.86-271.79)$ were found to be potent factors influencing the utilization of institutional delivery facility (Table 4). Similarly, respondents maternal and obstetric factors such as: age at first pregnancy $(\mathrm{COR}=5.91 ; 95 \% \mathrm{Cl}=2.34-14.91$; $\mathrm{p}<0.001)$, status of birth preparedness (COR $=51.78$; $95 \% \mathrm{Cl}=13.78-194.61 ; \mathrm{p}<0.001)$ and awareness of danger conditions during child birth (COR=26.73; 95\% $\mathrm{Cl}=7.41-96.37 ; \mathrm{p}<0.001$ ) were found to be statistically significant with utilization of institutional delivery in bivariate analysis. Those variables that show statistically significant at $95 \% \mathrm{Cl}$ in bivariate analysis were further analyzed for potential confounders through multivariate analysis. The variables were ethnicity, educational level of mothers, No. of ANC visit, place of delivery of previous baby and age at first pregnancy. The variables that had very small cell frequency were not included in multivariate analysis though statistically significant in bivariate analysis. It is worth to note that, after adjusting for potential confounder, the only variable which was independent predictors of the utilization of institutional delivery was found to be the number of ANC visit. The data revealed that, respondents with ANC visit of $\geq 4$ times were ten times more likely to utilize institutional delivery than those with less than four times $(A O R=10.03 ; 95 \% \mathrm{Cl}=1.02-98.29)$ (Table 4 and 5). 


\begin{tabular}{|c|c|c|c|c|c|}
\hline \multirow{3}{*}{ Variables } & \multicolumn{4}{|c|}{ Utilization of institutional delivery service } & \multirow{3}{*}{$\begin{array}{l}\text { AOR } \\
(95 \% \mathrm{Cl})\end{array}$} \\
\hline & Yes $(n=101)$ & No $(n=28)$ & $x^{2}(p-$ value $)$ & COR $(95 \% \mathrm{Cl})$ & \\
\hline & $n(\%)$ & $n(\%)$ & & & \\
\hline \multicolumn{6}{|l|}{ Age group } \\
\hline$<25$ & $44(75.9)$ & $14(24.1)$ & $0.367(0.545)$ &.- & \\
\hline$\geq 25$ & $57(80.3)$ & 14(19.7) & & & \\
\hline \multicolumn{6}{|l|}{ Ethnicity } \\
\hline Dalit & $8(44.4)$ & $10(55.6)$ & & Ref & Ref \\
\hline Janajati & $52(75.4)$ & $17(24.6)$ & $\begin{array}{r}21.715 \\
\left(<0.001^{*}\right)\end{array}$ & $\begin{array}{r}3.82(1.30- \\
\left.11.24^{* *}\right)\end{array}$ & $\begin{array}{r}1.58(0.18- \\
13.57)\end{array}$ \\
\hline Upper caste & $41(97.6)$ & $1(2.4)$ & & $\begin{array}{r}51.25(5.73- \\
\left.458.28^{* *}\right)\end{array}$ & $\begin{array}{r}27.04(0.57- \\
1278.24)\end{array}$ \\
\hline \multicolumn{6}{|c|}{ Respondents' educational status } \\
\hline Literate & $96(80.0)$ & $24(20.0)$ & $2.944(0.086)$ & & \\
\hline Illiterate & $5(55.6)$ & $4(44.4)$ & & & \\
\hline \multicolumn{6}{|c|}{ Respondent's educational level } \\
\hline Read and write only & $7(50.0)$ & $7(50.0)$ & & Ref & Ref \\
\hline Primary education & $18(58.1)$ & 13(41.9) & $\begin{array}{r}27.281 \\
\left(<0.001^{*}\right)\end{array}$ & $\begin{array}{r}1.38(0.39- \\
4.91)\end{array}$ & $\begin{array}{r}2.68(0.20- \\
34.55)\end{array}$ \\
\hline Secondary and above & $71(94.7)$ & $4(5.3)$ & & $\begin{array}{r}17.75(4.15- \\
\left.75.91^{* *}\right)\end{array}$ & $\begin{array}{r}1.72(0.11- \\
24.90)\end{array}$ \\
\hline \multicolumn{6}{|c|}{ Educational status respondent's husbands } \\
\hline Literate & $100(78.7)$ & $27(21.3)$ & $0.957(0.328)$ & & \\
\hline Illiterate & $1(50.0)$ & $1(50.0)$ & & & \\
\hline \multicolumn{6}{|c|}{ Education level of respondent's Husband } \\
\hline $\begin{array}{l}\text { Read and write } \\
\text { only }\end{array}$ & $2(25.0)$ & $6(75.0)$ & & Ref & - \\
\hline $\begin{array}{l}\text { Primary } \\
\text { education }\end{array}$ & $26(61.9)$ & $16(38.1)$ & $\begin{array}{r}30.942 \\
\left(<0.001^{*}\right)\end{array}$ & $\begin{array}{r}4.87(0.87- \\
27.14)\end{array}$ & \\
\hline $\begin{array}{l}\text { Secondary and } \\
\text { above }\end{array}$ & $72(93.5)$ & $5(6.5)$ & & $\begin{array}{r}43.20(6.86- \\
\left.271.79^{* *}\right)\end{array}$ & \\
\hline
\end{tabular}

"statistically significance at $\leq 0.05$ level, $B$ yates' correction, Ref: reference group **significant at $95 \% \mathrm{Cl}, \mathrm{COR}=$ crude odds Ratio, $A O R=$ adjusted odds ratio

\section{Table 5. Association of maternal and obstetric factors with utilization of institutional delivery service.}

\section{Utilization of Institutional delivery service}

Yes $(n=101) \quad$ No $(n=28)$
Variables
$\mathrm{n}(\%)$
$n(\%) \quad x^{2}(p-$ value $)$
COR
AOR

(95\% Cl)

$(95 \% \mathrm{Cl})$

Age at First Pregnancy

\begin{tabular}{|c|c|c|c|c|c|}
\hline$<20$ & $30(60.0)$ & $20(40.0)$ & $16.080\left(<0.001^{*}\right)$ & Ref & Ref \\
\hline$\geq 20$ & 71 (89.9) & $8(10.1)$ & & $\begin{array}{r}5.91(2.34- \\
\left.14.91^{* *}\right)\end{array}$ & $\begin{array}{r}19.57(0.43- \\
889.78)\end{array}$ \\
\hline
\end{tabular}




\begin{tabular}{|c|c|c|c|c|c|}
\hline \multicolumn{6}{|c|}{ No. of pregnancy } \\
\hline$\geq 2$ & $51(68.9)$ & $23(31.1)$ & $8.978\left(0.003^{*}\right)$ & Ref & - \\
\hline \multirow[t]{2}{*}{1} & $50(90.9)$ & $5(9.1)$ & \multicolumn{3}{|c|}{$4.51(1.59-$} \\
\hline & & & \multicolumn{3}{|c|}{$\left.12.79^{* *}\right)$} \\
\hline \multicolumn{6}{|c|}{ Place of delivery of previous baby } \\
\hline Home & $7(36.8)$ & $12(63.2)$ & $8.496\left(0.004^{*}\right)$ & Ref & Ref \\
\hline Health facility & $40(74.1)$ & $14(25.9)$ & & $\begin{array}{r}4.89(1.60- \\
\left.14.91^{* *}\right)\end{array}$ & $\begin{array}{r}2.52(0.34- \\
18.68)\end{array}$ \\
\hline \multicolumn{6}{|c|}{ Period of gestation at time of first ANC visit } \\
\hline $2^{\text {nd }}$ trimester & $30(56.6)$ & $23(43.4)$ & $24.906\left(<0.001^{*}\right)$ & Ref & - \\
\hline $1^{\text {st }}$ trimester & $71(93.4)$ & $5(6.6)$ & & $0.09(0.03-0.26)$ & \\
\hline \multicolumn{6}{|c|}{ No. of ANC visit } \\
\hline$<4$ & $17(51.5)$ & $16(48.5)$ & $18.713\left(<0.001^{*}\right)$ & Ref & Ref \\
\hline$\geq 4$ & $84(87.5)$ & $12(12.5)$ & & $\begin{array}{r}6.58(2.64- \\
\left.16.40^{* *}\right)\end{array}$ & $\begin{array}{r}10.03(1.02- \\
\left.98.29^{* *}\right)\end{array}$ \\
\hline \multicolumn{6}{|c|}{ Birth preparedness status } \\
\hline Not prepared & $14(35.9)$ & $25(64.1)$ & $59.12\left(<0.001^{*}\right)$ & Ref & - \\
\hline Prepared & $87(96.7)$ & $3(3.3)$ & & 51.78 & \\
\hline
\end{tabular}

$\left(13.78-194.61^{* *}\right)$

Awareness of danger conditions during childbirth
$\begin{array}{llrrr}\text { Unaware } & 24(49.0) & 25(51.0) & 39.955\left(<0.001^{*}\right) & \text { Ref } \\ \text { Aware } & 77(96.2) & 3(3.8) & & 26.73\end{array}$

\section{DISCUSSION}

The data in this study revealed that majority $(78.3 \%)$ had utilized health facilities for delivery while the rest $21.7 \%$ had delivered at home. This finding is in line with the study conducted in North West Ethiopia by Bayu et $\mathrm{al}^{4}$ and study by Paneru ${ }^{5}$ in Nepal where $74.3 \%$ and $72.9 \%$ of mothers had given birth in health facilities respectively. Similarly, the annual health report ${ }^{6}$ of Chitwan district, Nepal also supports that $83 \%$ of the delivery occurred in health care facilities. However, the finding contradicts with the results reported by Nepal Demography and Health Survey (NDHS) ${ }^{7}$ and study by Shah et $\mathrm{al}^{8}$ which depicts that only $35 \%$ and $55 \%$ of the birth took place in health facility. The variation in geographical feature of terai and hilly region may explain this difference as people in terai region can get easy access to health care institutions than those in hilly region unlike in hilly regions where road access is difficult because of geographical variation.

The findings of this study showed greater utilization of institutional delivery services was found among upper caste (Brahmin/Chhetri) compared to lower caste (dalit). Consistently, Brahmin/Chhetri was 1.2 times more likely to utilize delivery service as compared to Tamang and Danuwar ethnicity in one of the study conducted in Kavrepalanchok district of Nepal. ${ }^{9}$ Greater utilization of institutional delivery services among Brahmin/Chhetri might point the higher societal value given to Brahmin/Chhetri in Nepalese society because of which this particular caste group may have the greater accessibility to the services.

Higher education level has been the positive influencing factor for utilization of institutional delivery services in various studies, ${ }^{8,10,11}$ which further supports the finding of this study as well. Furthermore, the findings of $\mathrm{NDHS}^{7}$ also stated that the proportion of deliveries in a health facility is nearly four times higher among mothers with SLC and higher education (75\%) than among births to mothers with no education (19\%). This could be because, educated women would be self-aware about the benefits of institutional delivery and thus they would opt to visit institution to ensure good health of themselves and their baby. Likewise, respondents' husbands' educational level was also one of the factor that predicted institutional delivery service utilization. Respondents whose husbands had secondary and above level of education were more likely to have institutional delivery which was in line 
with that of study conducted by Paneru, ${ }^{5}$ Arba et $\mathrm{al}^{12}$ and Daniel and Desalegn. ${ }^{10}$ The possible explanation for this might be that educated husbands could be more open towards modern medicine and aware of the benefits of giving birth at health facilities and thus he could encourage his wife to give birth at health facility.

The binary logistic analysis revealed that respondents' age at first pregnancy was important factor associated with utilization of institutional delivery service in this study as respondents who became pregnant for the first time at age $\geq 20$ were 5.9 times more likely to utilize institutional delivery services than those respondents who were from $<20$ years age group. Abeje et $\mathrm{al}^{11}$ in their study reported that respondents who had become pregnant for the first time at the age of 20-24 years were 8.3 times more likely to deliver in health institution as compared to respondents with their first pregnancy at the age of $<15$ years.

The finding of this study showed that respondents who were primiparous were 4.5 times more likely to utilize institutional delivery service compared to mothers who had two or more number of pregnancies. The finding of the study was comparable to the study conducted by Amano et $\mathrm{al}^{13}$ which showed that mothers with first pregnancy were 2.41 times more likely to utilize institutional delivery service use than those who were multiparous. Woman at first pregnancy are quite nervous, excited and anxious about their first child. They don't want to take risk so tends to visit hospital to get services from skilled health care personnel. This may explain why, women at first pregnancy were found to utilize ANC service more often than women who already gave birth to at least one child.

Current study revealed that the increase frequency of ANC visit is directly linked to greater utilization of institutional delivery services. This finding is in line with the findings of another study ${ }^{9}$ conducted in Nepal which revealed that respondents who visited $\geq 4$ ANC were 2 times more likely to have had institutional delivery as compared to those respondents who had visited 1-3 times.

\section{CONCLUSIONS}

Government of Nepal has implemented various programmes to increase utilization of institutional delivery services, yet there exists lacunae in achieving $100 \%$ skilled delivery service utilization. More than half proportion of women $(78.3 \%)$ utilized institutional delivery services in this study however there still remains the need to focus on those women who gave birth at home. More efforts are required to identify those gaps by health service planners and work together with the community in creating awareness regarding importance of institutional delivery services.

\section{REFERENCES}

1. World Health Organization (WHO). Trends in maternal mortality: 1990 to 2013 estimates by WHO, UNICEF, UNFPA, The World Bank and the United Nations Population Division. Executive summary. 2014. [link]

2. Suvedi BK, Ajit P, Sarah B, Puri M, Chitrakar SR, Poudel P, et al. Nepal Maternal Mortality and Morbidity Study 2008/2009: Summary of Preliminary Findings. Kathmandu, Nepal. Family Health division, Department of Health Services, Ministry of Health, Government of Nepal. [link]

3. Hogan MC, Kyle JF, Naghavi M, Stephanie Y, Mengru W, Susanna, M, et al. Maternal mortality for 181 countries, 1980-2008: A systematic analysis of progress towards MDG5. The Lancet. 2010; 6736(10): 60518-33. [link]

4. Bayu H, Adefris M, Amano A, Abuhay M. Pregnant women's preference and factors associated with institutional delivery service utilization in Debra Markos Town, North West Ethiiopia: a community based follow up study. BMC Pregnancy Childbirth. 2015; 15: 15. [pubmed]

5. Paneru DP. Factors influencing delivery service utilization in rural areas of Dadeldhura district of Nepal. ParipexIndian Journal of Research .2014;3(7): 1-3. [link]

6. Annual Health Report of Chitwan. (2013). District Public Health Office, Ministry of Health and Population, Government of Nepal; Chitwan

7. Nepal Demographic and Health Survey (NDHS). Ministry of Health and Population, New ERA and ICF International, Kathmandu: Government of Nepal 2011. [link]

8. Shah R, Rehfuess EA, Maskey MK, Fischer R, Bhandari $\mathrm{PB}$, Delius M. Factors affecting institutional delivery in rural Chitwan district of Nepal: a community based crosssectional study. BMC Pregnancy Childbirth. 2015; 15 (27): 1-14. [pubmed]

9. Shrestha SK, Banu B, Khanom K, Ali L, Thapa N, Pedersen $\mathrm{BS}$, et al. Changing trends on the place of delivery: why do Nepali women give birth at home? Reprod Health. 2012; 9 (25). [pubmed]

10. Daniel B, Desalegn M. Institutional delivery service 
Factors Associated with the Utilization of Institutional Delivery Service among Mothers

utilization and associated factors among child bearing age women in Goba Woreda, Ethiopia. J Gynecol Obstet. 2014; 2(4): 63-70. [link]

11. Abeje G, Azage M, Setegn T. Factors associated with Institutional delivery service utilization among mothers in Bahir Dar city administration, Amhara region: A community based cross sectional study. Reprod Health. 2014; 11(1):22. [pubmed]
12. Arba MA, Darebo TD, Koyira MM. Institutional delivery service utilization among women from rural districts of Wolaita and Dawro Zones, Southern Ethiopia; a community based cross sectional study. PLOS ONE. 2016; 11 (3). [link]

13. Amano A, Gebeyehu A, Birhanu Z. Institutional delivery service utilization in Munisa Woreda, South East Ethiopia: a community based cross-sectional study. BMC Pregnancy Childbirth. 2012; 12: 105. [link] 